УДК 821.161.2(092)

DOI 10.31.65/2520-6966-2020-14f-98-112-130

Капленко О. М.

доцент кафедри української літератури, методики її викладання та журналістики

Ніжинського державного університету імені Миколи Гоголя

\title{
До питання типології жіночих образів у прозі Марії Матіос
}

Стаття присвячена презентації сучасного українського літературного процесу, зокрема творчості Марії Maтіос. Мета нашого дослідження розглянути базову тріаду типології жіночих образів на матеріалі прози мисткині. Ідеться, зокрема, про художні варіації втілення образів жінкистрадниці, жінки-матері і жінки-вигнанки.

Образ жінки-страдниці розелядається за найбільш резонансним романом письменниці "Солодка Даруся", зміст якого торкається трагічних подій української історії 30-70-х років XX століття. Проте історичні події - не головний предмет зображення у творі, у ньому насамперед ідеться про історію людської душі. Усе своє життя головна героїня спокутує дитячий несвідомий гріх. Ії трагедію посилюють образи болю, голосу, німоти, вічності, долі, перетворюючи роман на фрілософрію буття і страждання, болю і любові, долі народу і долі людини.

Образ жінки-матері розглянуто за повістю "Мама Маріца - дружина Христосрора Колумба". Феномен материнства тут розкривається за допомогою архетипної концепції Юнга про матір як психічну і фрізичну передумову існування дитини. Трагедія матері, ії відчуження від життя через смерть чоловіка проектує важку долю дитини і неминучу духовну, а згодом і фозичну травму ії самої.

Завершує тріаду образ жінки-вигнанки, досліджений на матеріалі повісті "Москалиия". Головна героїня, вигнана з дому, опиняється сам на сам перед невідомістю, небезпекою, самотністю. Проте у деяких випадках вигнання може акумулювати внутрішні сили, допомогти побороти образи, що й сталося з Москалицею. Жінка стає на шлях знахарства і допомагає людям. Свідомість жінки, таким чином, постає в різноманітних аспектах, моделюються такі буттєві ситуації, в яких максимально виявляє себе проблема внутрішньої свободи жінки та вибору нею життєвого шляху.

Ключові слова: жінка-страдниия, жінка-мати, жінка-вигнанка, Марія Матіос, сучасна українська проза.

Актуальність статті зумовлена кількома фракторами. По-перше, у центрі уваги перебуває сучасна жіноча проза, яка сьогодні і кількісно, і якісно утримує свого читача. По-друге, актуальність роботи зумовлена тим, що жіночі образи у нашій роботі розглядаються на матеріалі прози Марії Матіос - знакової письменниці у сучасному 
літературному процесі, творчість якої отримала потужний резонанс. 3'явилася ціла низка літературно-критичних праць, відгуків, рецензій, спрямованих на кодифікацію її творчого профрілю, і цей процес активно триває.

Тема типологізації жіночих образів на матеріалі сучасної української літератури $є$ доволі актуальною. Скажімо, показовою може бути стаття Т. Трофименко "7 типів жіночих образів сучасної української літератури: у чому сила, сестро?" [13], де авторка виокремлює типи жінки-жертви, жінки-берегині роду, жінки-борчині, фреміністки в історичному антуражі, self-made стерви, теплої жінки до кави, жінки й АТО, вказуючи еталонні тексти їхньої репрезентації. Щодо осмислення творчості Марії Матіос у цьому контексті, то варто назвати праці К. Ісаєнко [4], Н. Косинської [6], О. Покуль [11], Т. Крищишина [7] та ін.

Осмислюючи питання базової тріади типажів жінок у творчості Марії Матіос, ми виокремили образ жінки-страдниці, жінки-матері та жінки-вигнанки із опертям на еталонні тексти.

Образ жінки-страдниці постає зі сторінок роману "Солодка Даруся". Авторська кодифікація жанру - "Драма на три життя" - налаштовує читача на сприйняття відповідного пафосу. Після "солодкої" назви це змінює горизонт очікування реципієнта. Проте зміст роману "згущує" межі драми і скеровує у бік трагізму. Вже в анотації до роману читаємо: "Найвідоміший і найпопулярніший роман Марії Матіос "Солодка Даруся" справедливо назвали "трагедією, адекватною історії XX століття", а саму Дарусю - "образом майже біблійним" [10].

Укладаючи типологію жіночих образів, Т. Трофименко у згаданій статті кодифікувала Дарусю як жінку-жертву. Власне семантика понять жертви і страдниці суміжна, адже авторка зазначає: "Учасниця (хоча частіше - просто сучасниця) переломних історичних подій намагається протистояти антиукраїнським силам, але переважно пасивно. Жінка-страдниця, жертва режиму" [13].

Мотив страждання властивий більшості творів Марії Матіос, адже ця емоція, яку визначають як "сукупність вкрай неприємних, обтяжливих або болісних відчуттів живої істоти, при яких вона відчуває фрізичний i/або емоційний дискомфорт, біль, стрес, нестерпні муки" [12], переживається головними героїнями доволі болісно. А деякі розвідки про творчість письменниці виносять цей мотив у назву, як-от "Марія Матіос - страждання читацької душі" [8].

Проте роман "Солодка Даруся" вирізняється з-поміж інших текстів ще й жанровою близькістю до так званої "літератури страждання" ("мisery lit"), де "головний герой долає особисті травми, набуті в період дитинства. Оповідь у творах названого жанру, як правило, 
починається з періоду дитинства головного героя" [1]. 3-поміж окремих тематичних підвидів тяжіє до такого, "дозволяє заглянути в потаємні куточки людської душі та винести на загал не надто приємні особисті спогади". Дійсно, зміст роману "Солодка Даруся" торкається важких дитячих спогадів головної героїні, які примушують її страждати за скоєний вчинок.

Потужний історичний контекст твору, ідеологічний дискурс оголюють трагічні метаморфози моралі й етики того часу, проте це ніяк не вмотивовує страждань окремої особистості, а навпаки, оприявнює жорстоку сутність тих часів.

Образ жінки-матері змодельовано за повістю "Мама Маріца дружина Христофрора Колумба", уже сама назва якої чітко скеровує рецепцію читача у напрямку осмислення феномену материнства. А Ігор Зіньчук свій відгук про книгу так і називає - "Гімн материнству" [3]. Показовою також виступає присвята до повісті: "Кожній матері окремо..." Цей дискурс ще більш рельєфно прокреслює анотація до книги, увиразнюючи небуденність ситуації, так би мовити, її межовий характер, розгортання якої оприявнює механізми і фрорми дії материнської любові як такої: "Оповідь Марії Матіос про бездонність материнської любові співмірна хіба що з грецькою трагедією чи народним епосом" [9, с. 4]. Відповідно, читацька рецепція на різних рівнях сконцентрована насамперед навколо образу матері.

Осмислюючи сюжет повісті у контексті творчого профрілю Марії Матіос, уважаємо, що заявлений образ матері повноцінно може розкритися у контексті архетипного способу його потрактування - архетипу матері. Архетипи є закодованими, формалізованими зразками, моделями людської поведінки. За К. Юнгом, архетип - це "комплекс позаперсонального досвіду, а також образ, який концентрує навколо об'єкта такі психологічні ситуації, що представляють певну дію і структуру первісних образів колективної позасвідомої франтазії, i, нарешті, категорію символічної думки, яка організує уявлення, що надходять ззовні" [14]. Це вроджені тенденції в рамках колективного позасвідомого, що є внутрішніми детермінантами психічного життя людини.

Найважливішими К. Юнг вважає архетипи Матері, Дитини, Мудрого старого тощо. Юнгівська модель архетипу матері зводиться усвідомлення того, що носієм архетипу постає перш за все конкретна матір, оскільки першопочатково життя дитини невіддільне від неї і являє собою стан безсвідомої ідентичності. Вона - психічна, а також фрізична передумова існування дитини. 3 пробудженням Я-свідомості зв'язок між ними послаблюється. Це призводить до диференціації Я і матері, особисті якості якої стають все більш чіткими. 
Водночас Юнг зазначає, що зворотний бік материнського архетипу охоплює все таємне, приховане, темне, безодню та царство мертвих; все, що неминуче, як доля. Ця амбівалентність архетипу матері втілена Юнгом у формулі "любляча і страшна мати". Як зразок, Юнг наводить приклад Діви Марії, яка $є$ не лише матір'ю Бога, але також, згідно із середньовічними алегоріями, і його хрестом.

У повісті Марії Матіос через образ конкретної жінки Маріци Нямцу (у заміжжі Рибачук Марії Тодорівни) відбувається проекція на архетип матері із його амбівалентною природою. Іще до народження сина Маріца у хвилини "надмірного хвилювання й чекання, яке ставало нестерпним" [9, с. 9] почувала дві протилежні емоції - радість і страх: "I тоді жінка несамовито хрестилася: від страху, що збожеволіє на радощах і не встигне розказати своєму коханому Колумбові, що в них нарешті буде дитина" [9, с. 9]. Або радість і туга: "Ця невчасна, недоречна, безтямна радість до краю знесилювала жінку, бо так не в'язалася ні з чорною барвою ії вбрання, ні з чорним іï думанням" [9, с. 12]. Відразу після народження дитини - хлопчика подвійне відчуття не зникло, "знову й знову переверталося в ній добре й недобре одночасно" [9, с. 14].

За К. Юнгом, з архетипом матері насамперед асоціюються такі якості, як материнська турбота і співчуття, магічна влада жінки. Мати - домінантна фігура там, де відбувається магічне перетворення і воскресіння. Дивлячись на сина, Маріца, як ніхто інший, проєктувала міцний зв'язок дитини із батьком, керуючись виключно власними відчуттями, ніби намагаючись воскресити образ померлого чоловіка через немовля: "Маріца кілька разів на день витягувала 3-під подушки маленьку фротокартку Христофрора одразу після його народження - і тут-таки дивилася на нього живого: таким схожим на батька був щойно народжений малюк. /.../ I вона цілими днями не зводила очей з невинної дитини, ніби чекала, що немовля подасть їй бодай якийсь знак від батька" [9, с. 14]. Реалізуючи свою домінуючу роль матері, Маріца всупереч суспільному спротиву ("жодна сила на світі не змогла би переконати Маріцу") називає дитину батьковим іменем - Христофрором.

М. Матіос неодноразово підкреслює дивний погляд дитини "цілими днями водив мутно-ясним поглядом довкруж себе", "надовго втуплювався очима в землю", "немовля ніби випробовувало матір то ясними, то мутними очима", "хлопчик із каламутним поглядом". Саме через лексему "каламуть" письменниця підкреслює потужний фрізіологічний і психічний зв'язок немовляти із матір'ю, адже сама Маріца "не змогла би пояснити, звідки в ній бралася така каламуть" 
[9, с. 14]. Власне, відбувається порушення природного розвитку дитини як фізіологічно (не міг говорити, невиправдано швидко ріс), так і психічно (нервові напади, агресія). Я-свідомість дитини не виокремлюється у чітку структуру, а відповідно, зв'язок матері і дитини не послаблюється, як мусило би бути. I в якийсь момент Маріца чітко усвідомила, що "ії дитина - це насправді - вона сама... й подеколи вона думає, що сама травмована не менше, ніж ії нещасна дитина" [9, с. 33]. Усі свої сили, які здатна сконцентрувати матір, вона скеровує на дитину. Маріца послаблює зв'язок зі світом: вона звільняється з роботи (працювала вихователькою у дитячому садку), не спілкується із ріднею чоловіка, вона навіть не була на похоронах своїх батьків. Усі колишні пристрасті - любов до своєї "сонячної Молдавії", до музики і танців батьківщини, до чоловіка - усе це погасло в її очах: "Чим далі, тим більше чула, що любить його дужче, ніж любила колись живих своїх батьків, а далі - Христофора... любила його більше, ніж колись свою дівочу волю й безтурботність" [9, с. 32].

Залишившись наодинці зі своєю бідою, Маріца реалізує лише одну свою іпостась - матір. Проте підступне людське слово, наздогнавши Маріцу раптово, коли вона на річці прала білизну, розбило ії, "як молот порцеляну". Маріца, "нібито й зовсім розп'ята на водному хресті", сама, як і Марія Богородиця, стала хрестом для свого сина, бо останне речення повісті - "... Далі не було нічого, крім продовження драми..." [9, с. 47].

Таким чином, застосувавши обрану методологію архетипного потрактування образу жінки-матері у повісті Марії Матіос "Мама Маріца - дружина Христофора Колумба", можемо спізнати усю його глибину і семантичну неоднозначність.

Образ жінки-вигнанки змодельовано за повістю "Москалиця" [7] у контексті консрлікту суспільства та особистості. Я. Голобородько зауважує, що "Тексти Марії Матіос абсорбують, акумулюють, асимілюють такі величини, як "людина" і "соціум" /. . ./ Суспільство, загальна думка часом намагається змінити справді вічні непорушні істини та ті, що є вигідними для нього, воно виступає як один організм, павук, що тримає все у своїх руках, і тільки насправді сильні люди виживають у такій боротьбі інтересів і соціуму та власних переконань [2].

Коли людина і соціум не можуть співіснувати разом, зокрема коли суспільство не приймає до себе людину, у більшості випадків трапляється вигнання з боку соціуму і відчуження особистості. Основними ознаками відчуження у світосприйнятті сучасної людини фрілософрська думка визнає такі, як відчуття безсилля перед долею; розуміння відсутності сенсу існування, неможливості досягти якими- 
небудь діями очікуваний результат; сприйняття навколишнього середовища як світу, де не виконуються взаємні соціальні зобов'язання, зруйнована інституціолізована культура; відчуття самотності та виключності людини з існуючих соціальних зв'язків; відчуття втрати "справжнього Я", самовідчуження. Архетип вигнання з Райського Саду, на жаль, повторюється в нашому житті. Вигнання є випробуванням внутрішньої свободи, і ця свобода інколи лякає.

Початок історії головної героїні повісті - Северини - цілковито здатен був призвести до зневіри, апатії, самовідчуження. 3 самого дитинства вона відчуває ворожі погляди і дії своїх земляків через її походженням. Матір Северини зґвалтував військовий росіянин. Вона не дочекалась свого коханого з війни, загинула. Жінка покинула однісіньку дочку рости і залишила на все життя тавро "московського приплоду". Ситуація входження героїні у соціум дещо нагадує історію одного відомого персонажа роману Панаса Мирного та Івана Білика - Чіпки Варениченка, якого односельці охрестили "чортеням" через батька-двожона. Радість існування Северини була занадто далекою: "Світ чим далі - тим стає більше смутним та чорним. I не мають сили його звеселити ні квітучі гори, ні щебет невтомного птаства" [9, с. 23].

Проте Северина змогла акумулювати всі внутрішні сили протистояти самовідчуженню. Можливо, наслідком такої жахливої трагедії, яка була пережита в дитинстві, стало те, що серце Северини навчилося спокійно ставитися до всього, що з нею трапилося, жінка не могла не лише помститися жорстоким людям, які продовжували ображати її, але й допомагала їм своїм зіллям та відварами, коли вони до неї зверталися.

Світ не змінився. Люди продовжували остерігатися Северини: "Через отой дурний людський поголос про щезника на неї косо дивилися сільські газдиньки на службі Божій, відступаючи від Северини, як від скаженої" [9, с. 49].

Ще одним супутником вигнання героїні $є$ відсутність комунікації, іï життя супроводжується мовчанням: "Северині за слово треба платити. Навіть на оте різке, як удар батога в спину - "москалиця", нікому не відповіла й разу" [9, с. 9]. Головна героїня у такий спосіб намагається захиститися за муром небагатостівності, адже "мовчання - це стіна, що захищає мою інтимну сфреру, розділяє приватне і публічне, убезпечує мене. Мовчання - мій прихисток" [5].

Саме екзистенційний контекст дозволяє адекватно збагнути феномен мовчання. Скажімо, за М. Гайдеґґером, мовчазність (небагатослівність) як модус мовлення здатна виразно передати 
зрозумілість тут-буття. Саме мовчання $€$ найближчим до знання екзистенційної правди, допомагає здійснити Северині життєвий вибір: "Тільки мовчання й холодний розум ведуть її життям" [9, с. 59].

Северина в умовах вигнання могла розраховувати лише на себе. Така максимальна концентрація на своїх внутрішніх силах змогла виявити ії̈ внутрішню свободу навіть в умовах вигнання.

Таким чином, Марія Матіос у своїх творах зображує жінку, здатну на вчинок. I це зовсім не претензія на вітринний героїзм. Це важка боротьба із життєвими обставинами, щоденний подвиг жінки, скерований насамперед на реставрацію поруйнованої моралі.

\section{Література}

1. Бехта M. "Misery lit" - "література страждання": поняття, сутність та інтерпретація. Національна бібліотека України імені В. І. Вернадського: веб-сайт. URL: http://nbuv.gov.ua/UJRN/Nznuoaf_2013_36_32 (дата звернення: 11.04.2020).

2. Голобородько Я. Соціумний інтер'єр чи психологічний дизайн?: Художні дилеми Марії Матіос. Слово і час. 2008. № 12. С. 81-85.

3. Зіньчук І. Гімн материнству. Мислене древо: веб-сайт. URL: https://www.myslenedrevo.com.ua/uk/Sci/LiteraryStudies/Zinchuk/Matios.html (дата звернення: 14.04.2020).

4. Ісаєнко К. Особливості презентації жіночого образу у прозі Марії Матіос. Наукові записки Ніжинського державного університету імені Миколи Гоголя. Філологічні науки / відп. ред. Г. В. Самойленко. Ніжин: НДУ ім. М. Гоголя, 2011. С. 6-8.

5. Кебуладзе В. Мовчання й тиша. Тиждень. Ua: веб-сайт. URL: https://tyzhden. ua/Columns/50/181603 (дата звернення: 11.04.2020).

6. Косинська Н. Драматизм жіночих образів у прозі Марії Матіос: конфрлікт ґендерної ролі та ідентичності. Наукові праці. Філологія. Літературознавство: веб-сайт. URL: http:/litstudies.chdu.edu.ua/article/view/ 73447/68831 (дата звернення: 20.04.2020).

7. Крищишин Т. Типологія жіночих образів у літературних творах М. Матіос та М. Г. Кінгстон. Магістерський науковий вісник Тернопільського національного педагогічного університету імені Володимира Гнатюка. 2017. Вип. 27. С. 50-52.

8. Марія Матіос - страждання читацької душі. ЗОУНБ: веб-сайт. URL: https://zounb.zp.ua/comment/1898 (дата звернення: 11.04.2020).

9. Матіос М. Москалиця; Мама Маріца - дружина Христофрора Колумба: Вид. 2-ге. Львів: ЛА "Піраміда", 2011. 64+48 с.

10. Матіос М. Солодка Даруся. Львів: ЛА "Піраміда", 2005. 176 с.

11. Покуль О. Еволюція образу жінки-берегині у вимірі української постмодерної культури. Вісник Львівської національної академії мистецтв. 2016. Вип. 29. С. $130-140$.

12. Страждання. Вікіпедія: веб-сайт. URL: https://uk.wikipedia. org/wiki/\%D0\%A1\%D1\%82\%D1\%80\%D0\%B0\%D0\%B6\%D0\%B4\%D0\%B0\%D 0\%BD\%D0\%BD\%D1\%8F (дата звернення: 11.04.2020). 
13. Трофименко Т. 7 типів жіночих образів сучасної української літератури: у чому сила, сестро? Повага: веб-сайт. URL: https://povaha.org.ua/7typiv-zhinochyh-obraziv-suchasnoji-ukrajinskoji-literatury-u-chomu-syla-sestro/ (дата звернення: 10.04.2020).

14. Юнг К. Душа и миф: шесть архетипов. Большая онлайн библиотека e-Reading: веб-сайт. URL: https://www.e-reading.club/chapter. php/ 1022019/ 53/Yung_-_Dusha_i_mif._Shest_arhetipov.html (дата звернення: 12.04.2020).

\section{References}

1. Bekhta, M. (2013). "Misery lit" - "literatura strazhdannia": poniattia, sutnist ta interpretatsiia ["Misery lit" - "literature of suffering": the concept, essence and interpretation]. Natsionalna biblioteka Ukrainy imeni V. I. Vernadskoho: vebsait. URL: http://nbuv.gov.ua/UJRN/Nznuoaf_2013_36_32 (Last accessed: 11.04.2020) [in Ukrainian].

2. Holoborodko, Ya. (2008). Sotsiumnyi interier chy psykholohichnyi dyzain?: Khudozhni dylemy Marii Matios [Social interior or psychological design?: Artistic dilemmas of Maria Mathios]. Slovo i chas. № 12. 81-85 [in Ukrainian].

3. Zinchuk, I. (2010). Himn materynstvu [Hymn to motherhood]. Myslene drevo: veb-sait. URL: https://www.myslenedrevo.com.ua/uk/Sci/Literary Studies/ Zinchuk/Matios. html (data zvernennia: 14.04.2020) [in Ukrainian].

4. Isaienko, K. (2011). Osoblyvosti prezentatsii zhinochoho obrazu u prozi Marii Matios [Features of the presentation of the female image in the prose of Maria Mathios]. Naukovi zapysky Nizhynskoho derzhavnoho universytetu imeni Mykoly Hoholia. Filolohichni nauky / vidp. red. H. V. Samoilenko. Nizhyn: NDU im. M. Hoholia. 6-8 [in Ukrainian].

5. Kebuladze, V. Movchannia y tysha [Silence and silence]. Tyzhden. Ua: veb-sait. URL: https://tyzhden.ua/Columns/50/181603 (data zvernennia: 11.04.2020) [in Ukrainian].

6. Kosynska, N. Dramatyzm zhinochykh obraziv u prozi Marii Matios: konflikt gendernoi roli ta identychnosti [The Dramatism of Female Images in Maria Mathios' Prose: The Conflict of Gender Role and Identity]. Naukovi pratsi. Filolohiia. Literaturoznavstvo: veb-sait. URL: http://litstudies.chdu.edu.ua/article/ view/73447/68831 (Last accessed: 20.04.2020) [in Ukrainian].

7. Kryshchyshyn, T. (2017). Typolohiia zhinochykh obraziv u literaturnykh tvorakh M. Matios ta M. H. Kinhston [Typology of female images in the literary works of $M$. Mathios and MG Kingston]. Mahisterskyi naukovyi visnyk Ternopilskoho natsionalnoho pedahohichnoho universytetu imeni Volodymyra Hnatiuka. Vyp. 27. 50-52 [in Ukrainian].

8. Mariia Matios - strazhdannia chytatskoi dushi [Maria Mathios - the suffering of the reader's soul]. ZOUNB: veb-sait. URL: https://zounb.zp. ua/comment/1898 (Last accessed: 11.04.2020) [in Ukrainian].

9. Matios, M. (2011). Moskalytsia; Mama Maritsa - druzhyna Khrystofora Kolumba [Moskalytsia; Mother Marica, the Wife of Chrystopher Columbus]. Lviv [in Ukrainian].

10. Matios, M. (2005). Solodka Darusia [Sweet Darusia]. Lviv [in Ukrainian].

11. Pokul, O. (2016). Evoliutsiia obrazu zhinky-berehyni u vymiri ukrainskoi postmodernoi kultury [The evolution of the image of a guardian woman in the 
dimension of Ukrainian postmodern culture]. Visnyk Lvivskoi natsionalnoi akademii mystetstv. Vyp. 29. 130-140 [in Ukrainian].

12. Strazhdannia. Vikipediia: veb-sait. URL: https://uk. wikipedia. org/wiki/\%D0\%A1\%D1\%82\%D1\%80\%D0\%B0\%D0\%B6\%D0\%B4\%D0\%B0\%D 0\%BD\%D0\%BD\%D1\%8F (Last accessed: 11.04.2020) [in Ukrainian].

13. Trofymenko, T. (2017). 7 typiv zhinochykh obraziv suchasnoi ukrainskoi literatury: u chomu syla, sestro? [7 types of female images of modern Ukrainian literature: what is strength, sister?]. Povaha: veb-sait. URL: https://povaha.org. ua/7-typiv-zhinochyh-obraziv-suchasnoji-ukrajinskoji-literatury-u-chomu-sylasestro/ (Last accessed: 10. 04. 2020) [in Ukrainian].

14. lunh, K. Dusha y myf: shest arkhetypov [Soul and myth: six archetypes]. Bolshaya onlain biblioteka e-Reading: veb-sait. URL: https://www.ereading.club/chapter.php/1022019/53/Yung_-_Dusha_i_mif._Shest_arhetipov. html (Last accessed: 12.04.2020).

\section{Kaplenko O. M.}

Associate Professor of Ukrainian Literature, Methods of Teaching and Journalism Department, Nizhyn Mykola Gogol State University

\section{The Typology of Female Images in Maria Matios' Prose}

The article is devoted to the presentation of the contemporary Ukrainian literary process, in particular Maria Matios' works. This research offers a complex analysis of the basic triad of female images on the material of the author's prose. These are artistic variations of the embodiment of Sufferer, Mother and Exile female images.

The image of a suffering woman is considered based on the most resonant novel "Sweet Darusia", which content concerns the tragic events of Ukrainian history of the 1930-1970s. However, this novel is not about history, but about the story of a human's soul. Throughout her life, the main character atones for the child's unconscious sin. Her tragedy is exacerbated by the images of pain, voice, dumbness, eternity and fate, that turns the novel into a philosophy of existence and suffering, pain and love, fate of the people and fate of a human.

The female image of Mother is investigated based on the story "Mother Marica, the Wife of Chrystopher Columbus". The phenomenon of motherhood is revealed through Jung's archetypal conception of a mother as the mental and physical precondition for the existence of a child. Mother's tragedy and her alienation from life due to her husband's death project the difficult fate for the child and her own inevitable spiritual and physical trauma.

Exile female image is represented in the story "Moskalytsia". Exiled from home, the main character finds herself alone facing the unknown, danger and loneliness. However, this condition accumulates Moskalytsia's internal forces and helps to overcome resentment, which results in her embarking for the path of witchcraft and helping people.

Therefore woman's consciousness appears in various aspects and the problem of a woman's inner freedom and her choice of life path manifests itself in various existential situations.

Key words: Sufferer, Mother and Exile female images, Maria Matios, contemporary Ukrainian prose. 
УДК 821.161.2/82-3

$\mathrm{DOI}$

\section{Ж. О. Янковська}

доктор фрілологічних наук, професор кафедри культурології та фрілософії Національного університету "Острозька академія"

\section{Регіональні аспекти української прози доби романтизму}

Перша половина XIX століття - час становлення нової української літератури загалом та жанру прози зокрема. У творах цього часу можемо простежити чітку апеляцію до локальної місцевості проживання зображених героїв. Актуалізовано важливість дослідницьких студій в розвитку регіональних напрямків гуманітарної науки, осібно в літературі, що є естетично-художнім відображенням дійсності. Розкрито фоормування іншої естетичної системи як потреби нового освоєння й осмислення дійсності в період романтизму, яка, поєднавши елементи різних напрямів (сентименталізм, власне романтизм, реалізм), постала як органічна стильова цілість, заглиблена у культурну традицію народу. Проаналізовано окремі твори літературної прози доби романтизму на предмет ії прив'язаності до конкретного регіону та визначено головні ознаки такої ідентифрікації художнього твору в контексті локальної місцевості.

Визначено стилістичну близькість прозових творів доби романтизму до народного зразка. Охарактеризовано їх авторський компонент, синтезовану цілісність останнього, що впливає на їх сприйняття. Доведено належність стилю їх описів як від пануючих стилю та напряму в літературі, так і від індивідуального стилю автора. Виокремлено в низці головних критерії, на основі яких помітними є асоціації з конкретним регіоном, три: 1) мовна канва твору; 2) описи, чітко прив'язані до конкретної місцевості; 3) детальні, етнографрічно точні портрети героїв (антропоекфрразиси). Проаналізовано описові фррагменти прозових творів, що містять елемент регіональної прив'язаності до конкретної місцевості: "Вечори на хуторі біля Диканьки" М. Гоголя, асоціювання з Полтавщиною, Г. Квітки-Основ'яненка - із Слобожанщиною, Ганни Барвінок та П. Куліша - із Чернігівщиною, Київщиною. Мовленнєві аспекти художньої прози доби романтизму наразі достатньо досліджені або (в плані регіоналістики) заслуговують на окрему студію. Що ж стосується описів місцевості чи конкретного простору, то вони заслуговують на особливу увагу, тому й стали предметом дослідження у цій статmі.

Ключові слова: літературна проза доби романтизму, регіоналістика, екфразис (топоекфразис).

Регіоналістика як поліаспектна галузь вже сама по собі зумовлює дослідницькі студії в різних напрямках гуманітарної науки. Один 
із них - література, що є естетично-художнім відображенням дійсності. У статті маємо за мету проаналізувати окремі твори літературної прози доби романтизму на предмет ії прив'язаності до конкретного регіону. Головними ознаками такої ідентифрікації художнього твору із локальною місцевістю вбачаємо використання мовленнєвих одиниць, таких як діалектизми, фраземи й паремії, а також авторські описи конкретної місцевості (пейзажів, обійстя, інтер'єру) чи портретів героїв із детальними етнографічними характеристиками костюма.

Щодо мовленнєвого аспекту питання, то він більш висвітлений у науковій літературі, в тому числі й у авторській монографії "Фольклоризм української романтичної прози" [15]. Тому наразі сконцетруємося на описах. Для текстових прикладів обрані найбільш яскраві зразки із творів.

Авторський наратив Iпол. XIX ст. повністю закорінений в народну оповідну традицію. Виростаючи з неї (маємо на увазі малу прозу), він стимулює й розвиток великих епічних жанрів, зокрема, роману (йдеться про історичне полотно П. Куліша "Чорна рада").

Художні авторські описи у літературних творах цього часу ще не розлогі, особливо в малій прозі, позаяк, як зазначалося, зорієнтовані на народний наратив, що в своїй основі $€$ діалогічним. Проте й недооцінювати їх не можна, оскільки вони ніби обрамлюють зображені події, доповнюють сюжетну канву твору й визначають апелювання до конкретного регіону. Ці описи впливають на уяву, викликаючи зорові образи, які допомагають читачеві якнайглибше зануритися в події, епоху, обставу, ніби засвідчуючи свою причетність до описаного, а часто навіть викликаючи замилування, як справді малярським твором. Такі словесно-візуальні семантичні локуси в той чи інший період розвитку літератури переважно й визначають міру її "художності".

Попри стилістичну близькість до народного зразка, прозові твори доби романтизму вирізняються відчутним авторським компонентом, являючи собою синтезовану цілісність, що впливає на їх сприйняття. Стиль описів у них залежить як від пануючих стилю та напряму в літературі, так і від індивідуального стилю автора. Це ті смислові лакуни, які допомагають візуалізувати зображене у творі, з одного боку - переводять його у категорію мистецтва, а з іншого призначені для кращого розуміння описаних подій. У більшості випадків ці описи не просто глибоко національні за своєю суттю, а й регіонально відповідні та етнографічно правильні, оскільки відображають найчастіше або етнічний життєвий простір (природний чи побутовий, створений самими етнофорами) або національнолокальний естетичний ідеал людини (портрет). 
У період романтизму фрормується зовсім інша естетична система як потреба нового освоєння й осмислення дійсності, що, поєднавши елементи різних напрямів (сентименталізм, власне романтизм, реалізм), постала як органічна стильова цілість, заглиблена у культурну традицію народу. Під ії̈ впливом й відбувалося формування естетичних поглядів українського письменства того часу. Тому очевидно, що описи в прозових творах відображають так званий "національний код", що актуальний для будь-якого народу, належить до так званих "універсальних цінностей" і, на думку Я. Гарасима, визначає специфріку "етнічно маркованої ментальності" [4, с. 31]. Саме описові фррагменти прозових творів містять елемент регіональної прив'язаності до конкретної місцевості. Скажімо, твори М. Гоголя (із його "Вечорів на хуторі біля Диканьки") завдяки цим описам дуже прозоро асоціюються із Полтавщиною, Г. Квітки-Основ'яненка - із Слобожанщиною, Ганни Барвінок та П. Куліша - із Чернігівщиною, Київщиною і т. д. За комплексом ознак ці описи не позначають відмінних характеристик в окремо взятому населеному пункті (хоч іноді називають його), проте виразно асоціюються 3 конкретним етнографрічним регіоном. 3 іншого боку, саме через художній твір за межі локального простору "виводились" і ставали загальнонаціональним надбанням вузькоспецифічні культурні реалії, віддзеркалюючи інформативну, емоційну та естетичну фрункції авторської словесності.

Такі описи, орієнтуючись на народний ідеал, у той час кардинально змінюють призначення літератури, яка створювалася не лише для еліти, верхівки суспільства, але й для простого читача, побут і загалом життя якого стали предметом зображення у цих творах. Так, аналізуючи прозу Г. Квітки-Основ'яненка як представника сентименталізму та преромантизму, М. Яценко писав про те, що письменник, залучаючи окремі мотиви та сюжетні схеми із фрольклору, осмислює їх, і вони "розщеплюються, розкладаються індивідуальною суб'єктивною свідомістю автора" і вже "виступають не як цілісна естетична модель світу, естетико-етичний взірець, а тільки як матеріал, що використовується для досягнення достовірності художньої фрорми, найбільш сприйнятної і зрозумілої простонародному читачеві..." [16, с. 61]. У виграненому авторському творі письменники намагалися зачепити читача, показати естетичне у його іноді далеко не ідеальному житті. Це література не тільки про народ, але й для народу. Відповідно, народність виступає як її нова якість.

Загалом дослідники вже звертали увагу на художні описи, аналіз яких приводить нас до теорії екфрази, або екфразису, термінів, 
що й до сьогодні не вповні осмислені в українській гуманітаристиці. Первинно слово "екфрразис" перекладається з грецької як "виклад", "опис" і в літературознавстві означає "інтерсеміотичне розкриття засобами літератури ідейно-естетичного змісту творів малярства, скульптури, архітектури, музики та ін. мистецтв" [10, с. 325]. Проте сучасні вчені доводять, що екфразис може використовуватись у художньому творі не лише як опис готових візуальних творів мистецтва, але й як своєрідне "наштовхування", спонукання до створення наочних картин та образів у своїй уяві з допомогою словесних описів. Розширення семантики терміна шляхом інтердисциплінарного та поліфункціонального застосування й призвело до його дефініційної розмитості. Проте це лише збуджує інтерес до осмислення, викликає спроби чіткішого означення поняття. Свідченням цього можуть бути статті Т.Бовсунівської "Роман-екфрасис "Корабель дурнів" Грегорі Нормінтона" [3] та Н. Мочернюк "Проблеми художнього простору в екфррастичних описах" [13], де авторки, зрозуміло, не можуть оминути з'ясування семантики терміна.

На думку Т. Бовсунівської, екфразис на сьогодні навіть здатен переростати в окремий літературний жанр або фрорму оповіді, використовуватися не тільки в контексті твору, але й бути самостійним, транслюючи "метамову" культури й відображаючись наскрізно в парадигмі понять "мистецтво - література - культура". Авторка погоджується із думкою Синтії Волл, яка писала, що в літературі XX ст. "екфрасис дедалі більше відривається від його класичного розуміння живої репрезентації якогось із творів мистецтва, перестав бути частиною оповіді (додаючи слова й сцени до сюжету або актуальні міркування про явища мистецтва), обтяжуючи оповідь, стаючи самодостатнім та перериваючи основну оповідь" [Цит. за вид.: 3]. Тобто дослідниця не заперечує можливість навіть жанрового розвитку екфразису.

Отже, що стосується описів природи, пейзажів, ландшафтів, то в літературній прозі доби романтизму вони не надто поширені й тісно пов'язані з відображеними подіями. Цікаво, що в мистецтві цього періоду також ще немає окремих, суто пейзажних полотен. Пейзажний живопис знаходиться у зародковому стані й частіше служить тлом для портретного зображення. У літературі кількома десятиліттями пізніше описи розвинуться й стануть відносно самостійними елементами у прозі Панаса Мирного, І. Нечуя-Левицького та інших письменників. В авторській прозі аналізованого періоду описи природи найчастіше включають у себе як невід'ємну частину й житловий етнографічний комплекс певного регіону, конкретного місця проживання героїв: хату, 
подвір'я, садок та як їх продовження - город, леваду і т. д. Власне, це ті найближчі людині топоси буття, в яких проходить основна частина ії̈ життя. С. Кримський означив їх як "Дім", "Поле" і "Храм" [7].

Мабуть, найтиповішим зразком такої "природної" оселі $є$ опис Череваневого хутора з історичного роману П. Куліша "Чорна рада". Це в тодішньому розумінні українця ідеальний життєвий простір, що символізує гармонію людини й природи, яка сприяє її духовному самовдосконаленню й душевному спокою: "А те Хмарище було окрите гаями справді наче хмарами. Кругом обняла його річка з зеленими плавами й очеретами. Через річку йшла до воріт гребелька" $[9$, c. 38]. П. Куліш постав тут як майстер ідилічної пейзажно-побутової деталі. Словесний опис дуже лаконічний, проте у підтексті уявно-візуально проступає цілісна картина згармонізованого з природою хутора. Цей опис виступає не просто як національна деталь, а за романом відображає місцевість в околицях Києва: "Не доїздячи верстов зо дві чи зо три до Києва, взяли вони (йдеться про полковника Шрама та його сина Петра - Ж. Янковська) у ліву руку, да й побрались гаєм, по кривій доріжці. I хто тільки бачив, як вони з поля повернули в гай, усяке домислилось, куди вони простують. Крива доріжка вела до Череваневого хутора, Хмарища" [9, с. 38].

Дуже доречною тут є думка С. Кримського про те, що "знаковосимволічний лад буття" українців "пов'язаний з архетипом ставлення до природи", оскільки "в українському менталітеті природа - це не тільки материнський, родинний початок, а й дзеркало людської душі" [8, с. 28]. Дослідниця Н. Мочернюк, спираючись на визначення О. Клінга, відносить такі описи до "топоекфразисів", розуміючи під цим терміном "опис в літературному творі місця дії, яке несе на собі особливе естетичне навантаження" [13, с. 294].

До топоекфразисів можна віднести також описи життєвого простору, створеного самими людьми. Промовистим прикладом може бути ідилія, пов'язана зі зведенням оселі й облаштуванням обійстя на Чернігівщині, зображена в оповіданні Ганни Барвінок "Королівщина": "Як тільки мій батько ту хату окукобив: "Не мені, - каже, - буде, дак моїм дітям". Поклинцював ії, грузом набив, обставив очеретом навкруги, щоб тепліше. А сад який хороший у нас був там: сам нащепив. I невеличкий садок, довгенький, та вишняк хороший, дві яблуні й сажалка, над сажалкою похилилася калина. Сидимо, було, під рясним цвітом у спеку, як під дахом. Над самими сіньми яблуня розіп'ялась і два чорногузи гніздо звили. Наче й щастя пророкували [...]. Соловей не одно гніздо звив..." [1, с. 288]. 
Цитата містить символічні модуси українського житла як "схованки добра". Простір у ньому та навколо давав можливість зреалізувати власну свободу, створити світ, який відповідав би морально-духовним цінностям людини, її потребам, звичкам. У просторі навколо оселі $є$ все, що підтримує і прикрашає ії, робить близьким, рідним, символічним: і "вишняк хороший", що символізує зв'язок зі світом "вишнім", божественним та предками, і "яблуня" як знак здоров'я й достатку, дерево життя, яке виступає центром світобудови та центром освоєного людиною космосу, райським деревом; калина "над сажалкою" мислиться як одвічний символ дівоцтва, краси, України; i "два чорногузи гніздо звили", продовжуючи рід свій та пророкуючи його продовження людям; і "соловей не одно гніздо звив" - як високоестетичне кредо української пісенності й злагоди (ладу). Ганна Барвінок, спонукувана своїм чоловіком П. Кулішем, робила свої фольклорні записи в основному на Чернігівщині, тому за деякими, в тому числі й мовленнєвими, ознаками можемо вважати описаний простір не просто національним, а таким, що відповідає цьому регіону.

Помітне місце у текстах творів I пол. XIX ст. займають й топосно вужчі описи обстановки чи інтер'єру оселі. Це світ буття героїв, середовище, у якому вони живуть, а отже, воно певною мірою характеризує їх, бо створене ними самими. Це середовище можна характеризувати як внутрішню сутність топосу "Дім". Наприклад, у "Чорній раді" П. Куліша змальовано частини такого внутрішнього простору, що відображає житло козацького хутора Київщини: "Світлиця в Череваня була така ж, як і тепер буває в якого заможного козака (що ще то за луччих часів дід або батько збудував). Сволок гарний, дубовий, штучно покарбований; і слова із Святого Письма вирізані; вирізано і хто світлицю збудовав, і якого року. І лавки були хороші, липові, із спинками, да ще й килимцями позастилані. I стіл, і божник із шитим рушником округи..." [9, с. 48-49]. Згадані матеріальні об'єкти, описані з етнографічною точністю, "працюють" тут на правдиве зображення обстави того часу. Цікаво, що автор не наголосив на їх утилітарному призначенні, а символічне - прочитується у підтексті. Сволок (основна несуча балка) у цьому випадку символізує міцні устої патріархальної сім'ї, родини, що здавна закріплене у народній традиції.

Ідею сакрального "Дому" як родинного вогнища доповнено у романі описом пекарні, де стояла піч (уособлення родинного вогнища), випікався хліб: "Тілько ж Петру, Шрамовому синові, здалось найкраще у пекарні, хоч там не було ні шабель, ні сагайдаків, а тілько самі квітки да запашнії зілля за образами й поза сволоком, а на столі лежав ясний да високий хліб" [9, с. 49]. 
У малій прозі цього періоду також наявні описи внутрішнього інтер'єру житла. Дуже цікавим є такий майже документальний опис в оповіданні Ганни Барвінок "Нещаслива доля", де розповідь ведеться від самої авторки та передано її власні враження. Письменниця описує хату своєї приятельки Степаниди із села НепроходиЛіс на Чернігівщині: "Я люблю заходити в хати до моїх землячок: там так гарно! Влітку вони варять обід у сінях, коли не на дворі, через те хата як квітник. Чисто, ясно, прохолодно; образи в квітках та в шитих рушниках; за сволоком сухі гвоздики. По стінах наївні малюнки божественні чи сміховинні і рушники на кілочках; посеред сволока гвіздок забито, а на йому хазяїнова шапка висить; а з-за сволока визирає псалтир у письменного, а в неписьменного - карбіж, гребін та днище" [1, с. 87]. Це опис життєвого простору селянина з погляду людини, відрізненої від нього дещо іншими умовами життя та інтелігентним вихованням, а відповідно, здатної уже якоюсь мірою не лише до описового, але й аналітичного сприйняття цього простору. Проте талант Ганни Барвінок полягає й у тому, що в інших своїх творах вона вміє на ці ж реалії подивитися очима своїх героїв, відчути те, що відчувають вони, передати все так, як передали б вони. В архівах письменниці знаходимо детальні "ескізи" таких описів у їі фольклорних записах, які пізніше повністю або частково увійшли до її оповідань.

Про художню предметність як "певний реквізит реального, автентичного, достовірного" пише О. Манойлова. На ії̈ переконання, зображення предметів у творах служать для повнішого й правдивішого відображення світу, "тому неодмінною і достеменною складовою [...] художнього універсуму" письменника є "предметно-речовий окіл героя, антураж дії (місце, тло, обставини, умови, побутові дрібниці, предмети, речі, архітектурні об'єкти, споруди, будівлі тощо)" [11, c. 84].

Загалом опис оселі як власного буттєвого простору більше або менше наявний майже у кожному творі письменників того часу чи то оприявно, чи у підтексті, адже житло для українців - один із найбільш значущих архетипних компонентів традиційно-побутової культури, символ космічного зв'язку із Всесвітом, тепла, затишку, доброти. За словами О. Циганок, оселя - це "певний мікрокосмос, у замкненому просторі якого проходить родинне життя: тут споконвіку відбуваються різні трудові процеси - готують їжу, відпочивають, святкують сімейні події та відправляють обряди, в ньому зосереджуються всі численні зв'язки і взаємини між членами сім'ї" [14, с. 23]. 
Помітним художньо-естетичним засобом у літературі періоду романтизму $є$ контамінації на рівні вербального фольклорно-етнографічного портретування персонажів, що, відображаючи національне бачення краси, підноситься до народно-естетичного ідеалу, який найчастіше чітко ідентифрікується з певним регіоном. Фактично відбувається "перекодування" символічної мови естетико-етнографрічної семантики народного вбрання на "метамову" літератури. Маємо на увазі деталізоване словесне "малювання" етнографрічно досконалих портретів у творах М. Гоголя, Г. Квітки-Основ'яненка, П. Куліша, Ганни Барвінок, О. Стороженка та ін. У цих описах наочно, майже "іконічно" постають перед читачем герої, яких насправді можна вважати національними ідеалами дівочої (частіше) та парубочої краси. За аналогією творення терміна "топоефразис", такі описи можемо характеризувати як антропоекфразиси. Зважаючи на обсяг статті, матимемо розкриття їх семантики за дослідницьку перспективу.

Отже, аналізовані естетично наснажені описи, "словесні замальовки", або візуальні спостереження, в літературній прозі доби романтизму цілком логічно переходять у вербальні, які називаємо екфразисами, топоекфразисами й антропоекфра-зисами. Вони виділяються у загальній текстовій канві твору, являючи собою окремі епізоди, спрямовані на збудження уяви читачів, прагнення перевести їх мислення у майже мистецьку мисленнєво-мовленнєву площину. Можемо стверджувати, що в літературі цього періоду ці описи повністю зорієнтовані на народно-естетичний ідеал, відповідають конкретному регіону й становлять неабияку цінність для етнографів.

\section{Література}

1. Барвінок Ганна. Зібрання творів: у 2 т. / упоряд. В. Шендеровський, В. Яременко. Львів: БаК, 2011. Т. 1572 с.

2. Бовсунівська Т. Роман-екфрасис "Корабель дурнів" Грегорі Нормінтона. URL: http://www.philology.kiev.ua/library/zagal/Movni___konceptualni_2011_ 38/059_068.pdf

3. Гарасим Я. Національна самобутність естетики українського пісенного фольклору. Львів: НВФ "Українські технології", 2010. 376 с.

4. Кримський С. Архетипи української ментальності. Кримський С. Проблеми теорії ментальності / відп. ред. М.В.Попович. Київ: Наукова думка, 2006. С. 273-301.

5. Кримський С. Софрійні символи буття. Кримський С. Під сигнатурою Софрії. Київ: Видавничий дім "Києво-Могилянська академія", 2008. С. 21-29.

6. Куліш П. Чорна рада. Хроніка 1663 року. Куліш П. Твори: в 2 т., Київ: Наукова думка, 1984. Т. 1. С. 38-173.

7. Літературознавча енциклопедія: у 2 т. / Т. 1. автор-уклад. Ю. І. Ковалів. Київ: ВЦ "Академія", , 2007. 608 с. 
8. Манойлова О. Художній предмет як наукова проблема: історія та перспективи. Слово і Час. 2009. № 6. С. 83-90.

9. Мочернюк Н. Проблеми художнього простору в екфрастичних описах. Вісник Прикарпатського національного університету ім. Василя Стефраника. Іноземна фрілологія. Івано-Франківськ, 2014. Вип. 126. Ч. 1. C. 291-296.

10. Циганок О. Традиційна українська хата - важливий виховний простір. Вісник Чернігівського державного університету. Чернігів, 2012. Вип. 77. С. 43-48.

11. Янковська Ж. Фольклоризм української романтичної прози: монографія. Львів: НВФ "Українські технології", 2016. 610 с.

12. Яценко М. Т. Романтизм. Історія української літератури XIX століття: у 2 кн., / за ред. М. Г. Жулинського. Київ: Либідь, 2005. Кн. 1656 с.

\section{References}

1. Barvinok, Hanna (2011) Zibrannia tvoriv. u 2 t., T.1 (V.Shenderovskyi, V.Yaremenko Eds.). [Collected edition]. Lviv:BaK. [in Ukrainian].

2. Bovsunivska, T. Roman-ekphrasys "Korabel durniv" Hrehori Normintona. [Novel-ecphrasis "Ship of fools"] Publichne administruvannia - Public Administration: URL: http://www.philology. kiev.ua/library/zagal/ Movni i_konceptualni_2011_38/059_068.pdf (Last accessed: 16.05.2020) [in Ukrainian].

3. Harasym, Ya. (2010) Natsionalna samobutnist estetyky ukrainskoho pisennoho folkloru. [National identity aesthetics Ukrainian folk song]. Lviv: NVF "Ukrainski tekhnolohii". [in Ukrainian].

4. Krymskyi, S. (2006) Arkhetypy ukrainskoi mentalnosti. In M.V.Popovych (Ed.) S.Krymskyi. Problemy teorii mentalnoti (pp. 273-301). [Archetypes of the Ukrainian mentality. S. Krymskiy. Problems of theory mentality]. Kyiv: Naukova dumka. [in Ukrainian].

5. Krymskyi, S. (2008) Sofiini symvoly buttia. In S.Krymskyi Pid syhnaturoiu Sofii (pp. 21-29). [Sophia symbols of existence]. Kyiv: Vydavnychyi dim "Kyievo-Mohylianska akadmiia". [in Ukrainian].

6. Kulish, P. (1984) Chorna rada. Khronika 1663 roku. In P. Kulish. Tvory: v 2 t. (T.1, pp. 38-173). [Black council. Chronicle of 1663]. Kyiv: Naukova dumka. [in Ukrainian].

7. Literaturoznavcha entsyklopediia: u 2 t. (2007) (T. 1, ed. Yu.I.Kovaliv). [Literary encyclopedia]. Kyiv: VTs "Akademiia". [in Ukrainian].

8. Manoilova, O. (2009) Khudozhii predmet iak naukova problema: istoriia ta perspektyvy. [Art subject as a scientific problem: history and perspectives]. Slovo I Chas, № 6, 83-90. [in Ukrainian].

9. Mocherniuk, N. (2014) Problemy khudozhnioho prostoru v ekfrastychnykh opysakh. [Problems of artistic space in ephrastic descriptions]. Visnyk Prykarpatskoho natsionalnoho universytetu im. Vasylia Stefanyka. Inozemna filolohiia, Vyp. 126, Ch. 1. Ivano-Frankivsk, 291-296. [in Ukrainian].

10. Tsyhanok, O. (2012) Tradytsiina ukrainska khata - vazhlyvyi vykhovnyi prostir. [Traditional Ukrainian house - an important educational space] Visnyk 
Chernihivskoho derzhavnoho universytetu, Vyp. 77. Chernihiv, 43-48. [in Ukrainian].

11. Yankovska, Zh. (2016) Folkloryzm ukrainskoi romantychnoi prozy: [Folklore of Ukrainian romantic prose] Monohrafiia. Lviv: NVF "Ukrainski tekhnolohii". [in Ukrainian].

12. Yatsenko, M.T. (2005) Romantyzm. In Istoriia ukrainskoii literatury XIX stolittia: $u 2 \mathrm{kn}$ [Romanticism. History of Ukrainian literature of the XIX century] (kn. 1, ed. M. H. Zhulynskyi). Kyiv: Lybid. [in Ukrainian].

\section{Zh. Yankovska}

Doctor of Philology, Professor, Department of Cultural Studies and Philosophy

The National University of Ostroh Academy

\section{The Regional Aspects of Ukrainian Prose in the Romantic Era}

The first half of the 19th century is the period of formation of new Ukrainian literature as a whole and the prose genre in particular. This was the Romantic era, which was not a homogenous movement in Ukrainian literature and integrated elements of sentimentalism, romanticism itself, and realism. Literary works of that period were mainly focused on oral literature, especially the prose which literally "grew" out of the folk narrative, and thus is related to a particular region, which is easily recognizable in the texts. In this context, such names as M.Hohol, H.Kvitka-Osnovianenko, O.Storozhenko, Hanna Barvinok, P.Kulish and many others as well as their works are worth mentioning.

Among the main criteria, which identify the association with a certain region, there are the following three ones: 1) the story arc in which the main emphasis is made on paroemiac phraseological units; 2) descriptions that are clearly related to a certain area: landscapes, villages, yards, house interior (topoekphrasis); 3) detailed, ethnographically accurate portraits of characters (antropoekphrasis).

Different language aspect of fictional prose in the Romantic era either have been rigorously studied or, in case with regional studies, require a separate research. As for the description of a locality, or a particular space and portraits, they deserve close attention and are the subject of this study. They take a prominent place in the story arc of the works of this period, concurrently depicting the local tradition, the dominating style and movement in the literature, as well as the author's style, defining by this not only regional ties of this prose but also the degree of its "fictionality".

Key words: literary prose of the Romantic era, regional studies, ekphrasis (topoekphrasis). 